\title{
Impact of organic wastes on soil environment and yield of T-aman rice
}

\author{
MA Habib, R Khatun*, MS Hossen
}

Department of Environmental Science, Bangladesh Agricultural University, Mymensingh-2202, Bangladesh

\begin{abstract}
Organic wastes are rich in nutrients that can improve soil fertility and enhance crop yield. A study was conducted at the experimental field of Department of Environmental Science, Bangladesh Agricultural University, Mymensingh during July-December 2014 to examine the effect of different organic wastes on soil quality and rice yield. The experiment was laid out in a randomized complete block design (RCBD) taking five treatments with three replications. The treatments were: T1 (recommended chemical fertilizers), T2 (50\% farm waste $+50 \%$ poultry manure), T3 (50\% poultry manure $+50 \%$ municipal solid waste), T4(50\% cowdung $+50 \%$ farm waste) and T5 (50\% farm waste $+25 \%$ poultry manure $+25 \%$ cow dung). All wastes were applied at one time after final land preparation and before 15 days of rice (BRRI dhan 49) transplanting. Minimum and maximum soil moisture content was $26.16 \%$ and $30.83 \%$ recorded at $\mathrm{T} 1$ and $\mathrm{T} 2$ treatments and that of $\mathrm{pH}$ values were 5.26 and 5.93 at T3and T4 treatments, respectively. Incase of soil nutrient content, organic matter, $\mathrm{N}$ and $\mathrm{S}$ content was highest in $\mathrm{T} 2$ treatment and $\mathrm{P}$ and $\mathrm{K}$ contents were highest in $\mathrm{T} 4$ treatment whereas lowest values were observed in $\mathrm{T} 1$ treatment. $\mathrm{Pb}$ and $\mathrm{Cd}$ contents were highest at $\mathrm{T} 5$ treatment and lowest at $\mathrm{T} 1$ treatment. However, the values of $\mathrm{Pb}$ and $\mathrm{Cd}$ were below the permissible limit for agricultural soil. The highest grain yield (4.72 $\left.\mathrm{t} \mathrm{ha}^{-1}\right)$ was recorded in T4 treatment and the lowest grain yield (3.87 $\mathrm{t} \mathrm{ha}^{-1}$ ) was observed in T1 treatment. Considering crop yield and soil properties, treatment T4 was better compared to other treatments. The present study clearly indicated that the quality of soil and yield increased due to the application of organic waste compared to chemical fertilizer.
\end{abstract}

Key words: Organic waste, soil environment, nutrients and heavy metal status, rice yield

Progressive Agriculturists. All rights reserve

*Corresponding Author: rehana_envsc@yahoo.co.uk

\section{Introduction}

Waste is an unavoidable by-product of human activities and its production maintains positive relation with increasing population that is responsible for increasing the global pollution (Rathi, 2006). Waste volumes continue to rise, which leads to loss of resources and increases environmental risks. The waste management is considered to be one of the most serious environmental problems in Bangladesh. Bangladesh has minimal waste collection coverage which forces majority of the waste to be dumped in open lands which could pose a serious environmental and health hazards (Enayetullahet al., 2005). The land filling of biodegradable waste has proved to contribute to environmental degradation, mainly through the production of highly polluting leachate and methane $\left(\mathrm{CH}_{4}\right)$ gas. Reducing the amount of $\mathrm{CH}_{4}$ emitted from landfills is considered to be the greatest potential for reducing the overall climate change impacts of waste management.

The fertility status of soil in Bangladesh has been declining continuously due to intensive cropping and imbalanced use of chemical fertilizers. Nutrient mining, depletion of soil organic matter, reduction in soil aggregates etc. have been identified as reasons of yield stagnation or decline in the productivity of crops (Rahman and Yakupitiyage, 2006). A good soil should have at least $2.5 \%$ organic matter, but in Bangladesh most of the soils have less than $1.5 \%$, and some soils even have less than $1 \%$ organic 
matter (BARC, 2005). The addition of different types of organic wastes to soil (crop residues, MSWcompost, cow dung, poultry manure, etc.) attenuates the degradation process of soil native organic matter. On the other hand, upon its proper management waste may treat an important resource because it can reduce the costs of commercial fertilizer as well as environmental hazards.

However, there is general consensus in the scientific literature that some composted waste materials contain larger concentrations of heavy metals (e.g., $\mathrm{Zn}, \mathrm{Cu}, \mathrm{Ni}, \mathrm{Cd}, \mathrm{Pb}, \mathrm{Cr}$ and $\mathrm{Hg}$ ) than the background values present in soil. The long-term accumulations of heavy metals in the soil environment potentially have important consequences on the quality of the human food chain, toxicity to plants and soil microbial processes. Therefore, it is important to evaluate soil quality and crop yield under the application of different waste materials on agricultural land.

The agriculture of Bangladesh is governed by intensive rice cultivation. About 11.7 million hectares cultivable land is used for rice cultivation (BBS, 2012). Therefore, the present study was proposed with a view tofinding out the impacts of recycling of waste materials on soil environment as well as the yield of rice crop.

\section{Materials and Methods}

Site description: The experiment was conducted in the field of Department of Environmental Science, Bangladesh Agricultural University, Mymensingh. The experimental field is located at $24^{\circ} 54^{\prime \prime} \mathrm{N}$ latitude and $90^{\circ} 50^{\prime \prime} \mathrm{E}$ longitudes at a height of $18 \mathrm{~m}$ above the mean sea level. The soil belongs to the "Old Brahmaputra Floodplain", under Agro-Ecological Zone-9 (UNDP and FAO, 1988). The climate of the study area is characterized by high temperature, high humidity and heavy rainfall with occasional breezy winds during kharif season and low temperature and low humidity during rabi season.

Experimental design and layout: The study was carried out during aman season (kharif-2) from 20 July to 28 November, 2014.The experiment was laid out in a randomized complete block design
(RCBD) with 5 treatments and 3 replications. Thus total unit of plots were 15 . The area of each plot was $4 \mathrm{~m}^{2}(2 \mathrm{~m} \times 2 \mathrm{~m})$. There were 3 blocks in the field. Between each block there was $50 \mathrm{~cm}$ drain. The total area of the experimental plot was $60 \mathrm{~m}^{2}\left(15 \times 4 \mathrm{~m}^{2}\right)$.The treatments were:

T1: 100\% Recommended fertilizer dose (urea, TSP, MOP, Sulphur and Zinc at the rate of 195, 21, 59, 60 and $4 \mathrm{~kg} \mathrm{ha}^{-1}$, respectively.)

T2: $50 \%$ Farm waste $+50 \%$ Poultry waste $\left(5.13+2.7\right.$ tha $\left.^{-1}\right)$

T3: $50 \%$ Poultry waste $+50 \%$ Municipal solid waste $\left(2.7+6.39\right.$ tha $\left.^{-1}\right)$

T4: 50\% well decomposed cowdung $+50 \% \quad$ Farm waste $\left(6.45+5.13\right.$ tha $\left.^{-1}\right)$

T5: $50 \%$ Farm waste $+25 \%$ Poultry waste $+25 \%$ well decomposed cowdung $\left(5.13+1.35+3.2\right.$ tha $\left.^{-1}\right)$

In this study impact of organic waste was compared with $100 \%$ recommended fertilizer dose.

Cultivation procedure: The experimental plot was ploughed with tractor on August 01, 2014. It was ploughed and cross ploughed followed by laddering to get hold of the attractive tilth. Then it was cleaned by removing weeds, crop residues and stubbles. The total doses of organic wastes were applied at one time after final land preparation and that was before 15 days of transplanting. Thirty-day old seedlings of BRRI dhan 49 were transplanted on 08 September 2014, maintaining row to row distance $20 \mathrm{~cm}$; hill to hill distance $20 \mathrm{~cm}$ and 3 seedlings per hill. Necessary gap filling was done at 8 days after transplanting. Weeding was done when necessary. Insecticides and pesticides were applied two times in a growing season for insect and pest management.

Collection, preparation and analysis of soil and plant sample: Soil samples were collected from $0-20 \mathrm{~cm}$ soil depth prior to application of well decomposed waste materials and after harvest for the analysis of soil physical and chemical properties such as i) soil texture, ii) soil moisture, iii) soil $\mathrm{pH}$, iv) electrical conductivity (EC), v) organic matter (OM), vi) total nitrogen $(\mathrm{N})$, vii) available phosphorus (P), viii) exchangeable potassium (K) ix) available sulphur (S) and $\mathrm{x}$ ) heavy metal (lead, $\mathrm{Pb}$ and cadmium, $\mathrm{Cd}$ ). Analyses weredone following standard methods. 
To measure plant height and leaf area index (LAI), three hills were randomly collected from each unit plot of five treatments from tillering to mature stage. The rice was harvested at full maturity on 22 November 2014. The grains were separated and sun dried for 5 days for attaining the moisture up to $14 \%$. The grains were kept in paper bags plot wise and weighted in $\mathrm{kg}$ and finally converted into $\mathrm{tha}^{-1}$.

Data analysis: Data on different parameters were statistically analyzed to find out the significance of different treatments. The means for all the treatments were calculated and analyses of variation of all the characters were performed by F-test. The significance of the difference between the pair of means was evaluated at $5 \%$ level of significance by Least Significant Difference (LSD) test using MSTAT-C computer package program (Gomez and Gomez, 1984).

\section{Results and Discussion}

Effect of organic wastes on soil texture, moisture content and soil $\mathbf{p H}$ : Sand, silt and clay ranged from 24-27\%, 67-70\% and 5-7\%, respectively at different treatments and there were no significant variations in

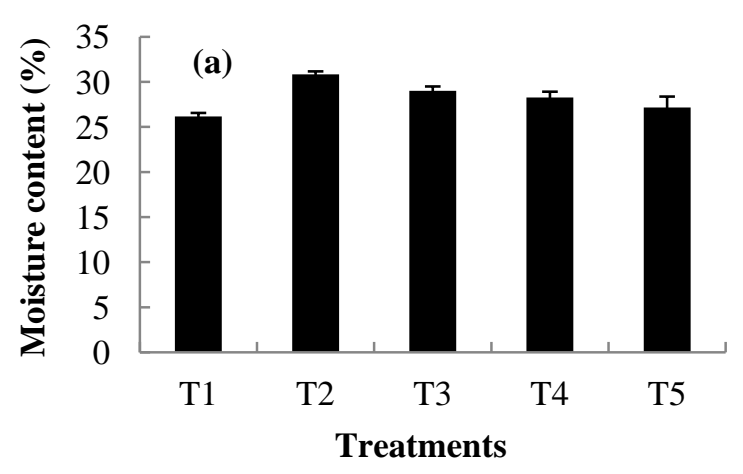

Figure. 1 Effect of organic wastes on (a) soil moisture content and (b) soil pH

Effect of organic wastes on soil organic matter (OM) content and electrical conductivity (EC): Organic matter content was significantly increased in all treatments (ranged from 2.28-2.83\%) relative to the initial soil (1.53\%). The highest organic matter content $(2.83 \%)$ was observed in $\mathrm{T} 2$ treatment and the lowest (2.28 \%) was noted at T1 treatment (Fig. 2a). The variation in $\mathrm{OM}$ at all the treatments followed the order ofT3 textural class among different treatments. The moisture content of the experimental plots ranged from $26.02 \%$ to $30.83 \%$ at different treatments (Fig. 1a). The highest soil moisture content (30.83\%) was recorded at $\mathrm{T} 2$ treatment (50\% poultry waste+ $50 \%$ municipal solid waste)whereas the lowest (26.02\%) was recorded at $\mathrm{T} 1$ (100\% recommended fertilizer dose) treatment. Addition of poultry waste + municipal solid waste in soil increased the moisture holding capacity and hence, the soil moisture content increased. Similar results were obtained by Ali (1994); Hussain and Jilani (1992) and Swarup (2000).

The $\mathrm{pH}$ values of the experimental plots ranged from 5.26 to 5.93 at different treatments (Fig. 1b). The highest $\mathrm{pH}$ (5.93) was observed at $\mathrm{T} 4$ treatment (50\% cowdung $+50 \%$ farm waste) and the lowest value (5.26) observed at T3 treatment (50\% poultry waste $+50 \%$ municipal waste). Soil $\mathrm{pH}$ decreased in all treatments relative to the initial soil (6.3). However, there were no significant variations in $\mathrm{pH}$ among different treatments. All the soils were slightly acidic in nature.

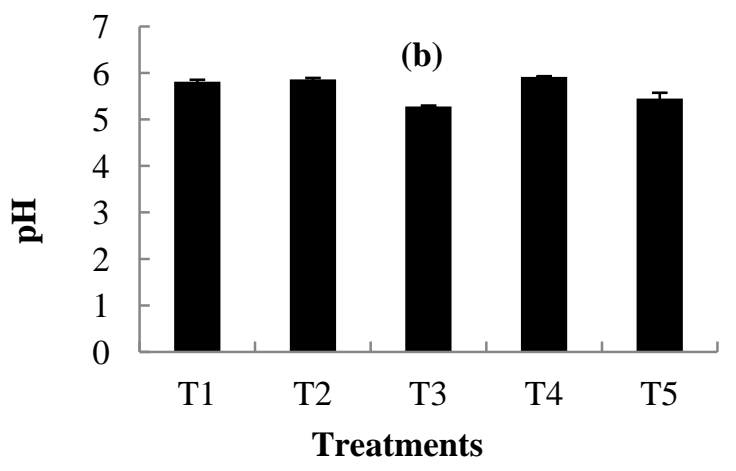

respectively. An increase in soil OM through the application of waste materials has also been found in previous studies (Kabirinejad and Hoodaji, 2012; Walter et al., 2000). Raju and Reddy (2000) reported that after five years of continuous cropping, all the organic manures plots had higher OM than that of inorganic fertilized plot. This may possibly owing to recycling of more OM from the crop stubbles in the field (Swarup and Sing, 1989). 
The values of EC ranged from 38.5 to $54.7 \mu \mathrm{S} / \mathrm{cm}$ at different treatments (Fig. 2b). EC was highest (54.7 $(\mu \mathrm{S} / \mathrm{cm})$ at $\mathrm{T} 3$ treatment and lowest $(39.03(\mu \mathrm{S} / \mathrm{cm})$ at T1 treatment. From the Fig. $2 b$, it is found that EC values did not differ significantly among different treatments. However, the EC values in all treatment were increased relative to the initial soil status (33.1 $\mu \mathrm{S} / \mathrm{cm})$. The reason for increasing EC might be due to the increased organic matter at all treatments.
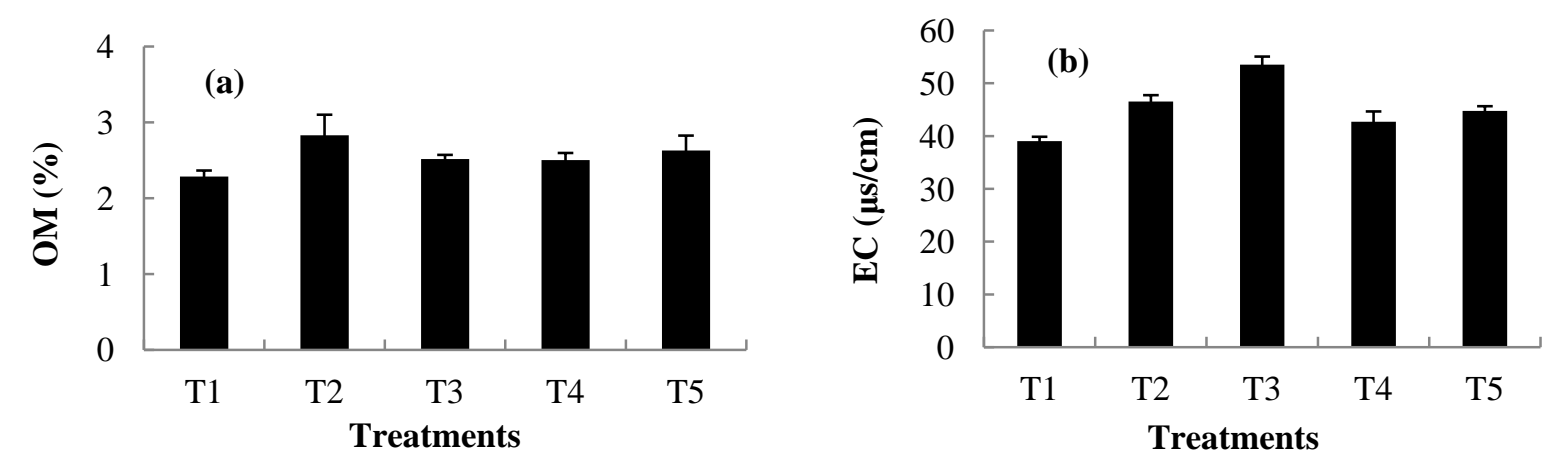

Figure 2. Effect of organic wastes on soil (a) organic matter (OM) content and (b) electrical conductivity (EC)

Effect of organic wastes on nutrient status of soil: The total $\mathrm{N}$ content of soil was significantly influenced due to the combined effects of different organic waste treatments. The highest value of $\mathrm{N}$ $(0.162 \%)$ was observed at $\mathrm{T} 2$ treatment and the lowest $(0.128 \%)$ was observed at $\mathrm{T} 1$ treatment (Fig. 3a). The treatments can be ranked in the order of $\mathrm{T} 2>\mathrm{T} 5>\mathrm{T} 4>\mathrm{T} 3>\mathrm{T} 1$, respectively for total $\mathrm{N}$ content. An increase in $\mathrm{N}$ through the application of waste materials has also been found in previous studies (Kabirinejad and Hoodaji, 2012; Walter et al., 2000). The P content varied from 12.09 to $17.34 \mathrm{ppm}$ at different treatments (Fig. 3b). The highest value (17.34 ppm) was recorded in T4 treatment and the lowest value (12.007 ppm) was recorded in T3 treatment. In case of available P, the treatments can be ranked in the order of $\mathrm{T} 4 \mathrm{~T} 5>\mathrm{T} 2>\mathrm{T} 1>\mathrm{T} 3$, respectively. Suwara and Kulesza (1990) reported that, application of mineral; FYM and combined mineral + FYM influenced soil $\mathrm{pH}$, organic carbon, total N, available P, K and Mg content of soil.

Exchangeable $\mathrm{K}$ content of soil significantly influenced by different organic waste treatments (Fig. 3c). The maximum value of exchangeable $\mathrm{K}$ (51.34 ppm soil) was observed at T4 treatment and the lowest (34.23 ppm) was recorded at T1 treatment. The treatments may be ranked in the order of T4> T5 $>\mathrm{T} 3>\mathrm{T} 1>\mathrm{T} 2$, respectively for $\mathrm{K}$ content.
Crisman (1995) reported a significant increase in K of soil with the application of organic materials.

From the Fig. 3d, it is found that available S content varied among different treatments. In all treatments, available S content was increased compared to inorganic fertilizer treatment (T1) as well as initial soil (8.02 ppm)). The highest available S (12.15 ppm) was observed in treatment T2 followed by T4 treatment and the lowest (9.68 $\mathrm{ppm}$ ) was observed in T3 treatment which was less than T1 treatment. Golabaiet al. (2007) and Silva et al. (2005) observed that concentration of $\mathrm{P}, \mathrm{K}$ and $\mathrm{S}$ increased after application of organic matter over control due to the decomposition of organic matter.

Effect of organic wastes on heavy metal status of soil: The lead $(\mathrm{Pb})$ content ranged from 9.5 to 12 ppm at different treatments (Fig. 4a). The highest $\mathrm{Pb}$ content (12 ppm) was recorded at treatment T5 and lowest $(9.5 \mathrm{ppm})$ was recorded in $\mathrm{T} 1$ treatment. Cadmium (Cd) content varied from 2 to $4.17 \mathrm{ppm}$ at different treatments (Fig. 4b). The Cd content was highest $(4.67 \mathrm{ppm})$ in $\mathrm{T} 5$ treatment and the lowest value (2.0 ppm) was recorded at T1 treatment. The treatments can be ranked in the order of $>T 53>$

$\mathrm{T} 2>\mathrm{T} 4>\mathrm{T} 1$, respectively for $\mathrm{Pb}$ and $\mathrm{Cd}$ content. According to WHO (1996), the maximum permissible limits of $\mathrm{Pb}$ in soil is $38 \mathrm{ppm}$ and the 
permissible limits of $\mathrm{Cd}$ ranges between $0.45-4.17$ $\mathrm{ppm}$. The $\mathrm{Pb}$ and $\mathrm{Cd}$ contents of all the treatments were lower than the permissible limit.
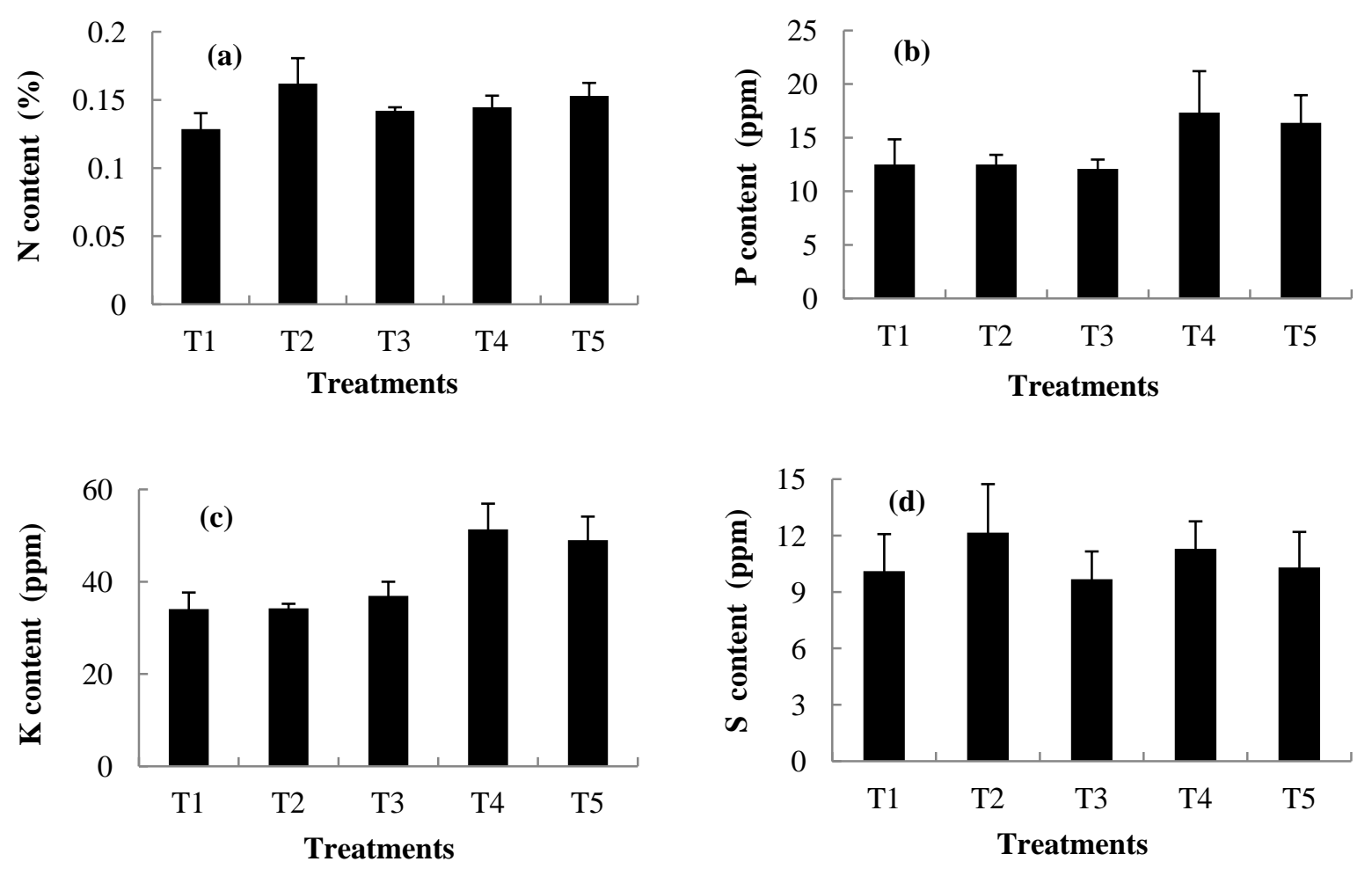

Figure 3. Effect of organic wastes on soil (a) nitrogen (N) (b) phosphorus (P) (c) potassium (K) and (d) sulphur (S) content
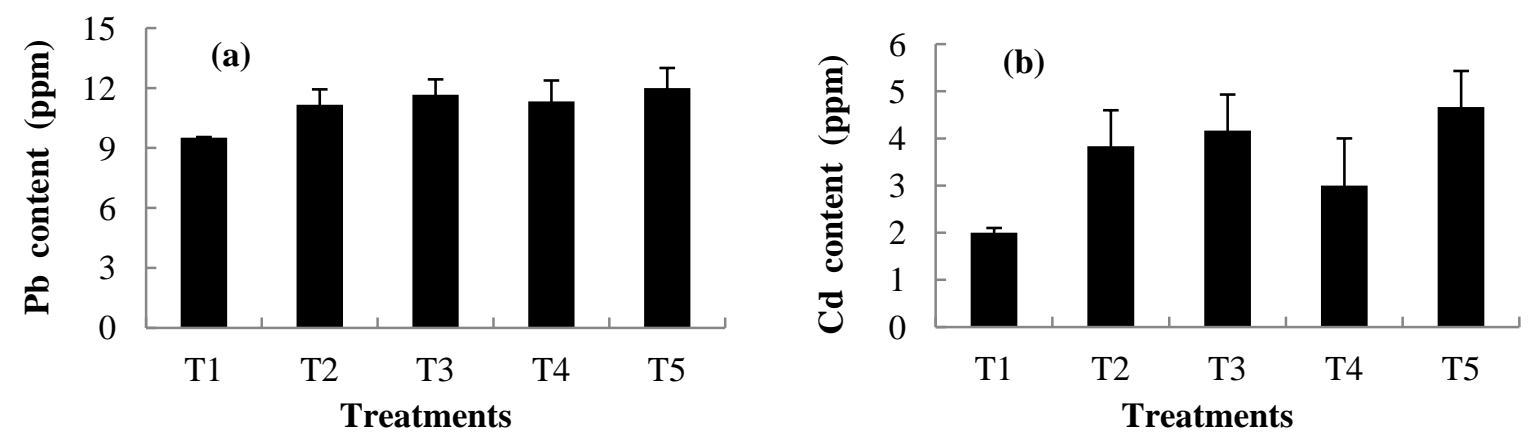

Figure 4. Effect of organic wastes on soil (a) lead (Pb) and (b) cadmium (Cd) content

Effect of organic wastes on crop yield: The variation in grain yield was highly significant due to the application of different treatments of organic wastes and $100 \%$ recommended fertilizers dose (Table 1 ). The highest grain yield $\left(4.72 \mathrm{t} \mathrm{ha}^{-1}\right)$ was found in T4 treatment and the lowest $\left(3.870 \mathrm{t} \mathrm{ha}^{-1)}\right.$ was obtained in $\mathrm{T} 1$ treatment. The treatments can be ranked in the order of $\mathrm{T} \& \mathrm{~T} 3>\mathrm{T} 5>\mathrm{T} 2>\mathrm{T} 1$ for grain yield. It is important to note that, plant height and leaf area index (LAI) were also highest in T4 treatment. Most of the soil components as well as plant height and LAI were higher in T4 treatment which contributed to higher yield in $\mathrm{T} 4$ treatment. Application of cowdung encouraged the vegetative growth of rice in terms of plant height and number of tillers hill $^{-1}$ which ultimately resulted in the increase of grain 
yield (Mishra et al., 2003). It is found that proper utilization of organic wastes give more yield with maintaining soil quality compared to $100 \%$ recommended fertilizer.

Table 1.Effect of organic wastes on yield of rice

\begin{tabular}{cc}
\hline Treatment & Grain yield $\left(\mathrm{t} \mathrm{ha}^{-1}\right)$ \\
\hline T1 & $3.870 \mathrm{c}$ \\
T2 & $3.910 \mathrm{c}$ \\
T3 & $4.290 \mathrm{~b}$ \\
T4 & $4.723 \mathrm{a}$ \\
T5 & $4.170 \mathrm{bc}$ \\
\hline CV (\%) & 3.75 \\
Level of & $* *$ \\
significance & \\
\hline
\end{tabular}

** = Significant at $1 \%$ level of probability

This study indicated that most of the nutrient contents and yield were higher at T4 treatment. On the other hand, $\mathrm{Pb}$ and $\mathrm{Cd}$ content were lower at $\mathrm{T} 4$ treatment. Therefore, T4 treatment i.e., uses of combination of farm waste and cowdung ismore suitable compared to other treatments.

\section{References}

Ali MI (1994). Nutrient balance for sustainable agriculture. Proc. Workshop integrated nutrient management or sustainable Agric. SRDI, Dhaka, June 26-28.

BARC (Bangladesh Agricultural Research Council) (2005). Fertilizer Recommendation Guide, BARC, Soils publication number 45. Bangladesh Agricultural Research Council, Farmgate, Dhaka.

BBS (Bangladesh Bureau of Statistics) (2012).(Statistical Year Book of Bangladesh).Ministry of Planning, Government Peoples Republic of Bangladesh .pp. 122-124.

Crisman KG (1995). The influence of moisture regime, organic matter and root ceophysiology on the availability and acquisition of potassium implication for tropical low land rice.Agrochemicals News in Brief 18(2): 3-12. Cited from Field Crop Abstract 49(7-10): 728.8

Enayetullah I, Khan SSA, Sinha, AHM (2005).Urban Solid Waste Management. Scenario of
Bangladesh: Problems and Prospects. Waste Concern Technical Documentation.

Golabai MH, Denney MJ, Iyekar C (2007).Value of composted organic wastes as an alternative to synthetic fertilizers for soil quality improvement and increased yield. Emmaus, USA. Composting Science and Utilization.15(4).

Gomez KA, Gomez AA (1984). Statistical Procedures for Agricultural Research 2nd edition.International Rice Research Institute Los Banos Laguna, The Philippines .pp 62-74.

Hussain T, Jilani G (1992). Integrated nutrient management studies under ricewheatcrooping system in Panjab, Pakistan, In Proc. Nutrient management for sustained productivity, Bajwa et al. (eds),PunjubAgril. Univ, Ludhiana. 140141.

Kabirinejad, Hoodaji (2012), International Journal of Recycling of Oraganic Waste in Agriculture. 1: 4.

Mishra OT, Tomar VS, Sharma RA, Rajput AM(2003).Response of Rice to organic and inorganic fertilizers, Crop Research. 9(2): 233-237.

Rahman MM, Yakupitiyage A (2006). Use of fishpond sediment for sustainable aquacultureagriculture farming.International Journal of Sustainable Development and Planning.1: 192202.

Raju RA and Reddy MN (2000). Sustainability of productivity in rice (Oryza sativa)-rice sequential cropping system through integrated nutrientmanagement in coastal ecosystem. Indian Journal of Agronomy. 45(3): 447-452.

Rathi S (2006). Alternative approaches for better municipal solid waste management in Mumbai, India. Waste Management. 26(10): 1192-1200.

Silva SHSA, Chandrapala AG, Jayalath HAP (2005). Evaluation of different organic manures on soil properties, growth and yield of rice and maize under rice-maize crop rotation.Peradeniya, Srilanka. Annals of the Srilanka, Department of Agriculture.l 7:87-94.

Suwara I, Gawronska-Kulesza A (1990). Effect of long-term fertilization and 3-field crop-rotation 
on some properties of soil.Zeszyty-NaukoweAkademii-Rolniczej-We-Wroclawiu.

Rolnictwo (Poland). 196(53): 211-217.

Swarup A (2000). Effect of integrated nutrient management on soil properties and yield of rice in alkali soils. J. Indiun Soc. Soil Sci. 48 (2): 279-282.

Swarup A, Sing KN (1989). Effect of 12 years rice wheat cropping sequence and fertilizer use on soul properties and crop yields in sodic soils. Field Crops Res. 21: 277-287.

UNDP (United Nations Development Program) and FAO (Food and Agricultural Organization (1988). Land Resources Appraisal of
Bangladesh for Agricultural Development. Report 2, Agroecological Regions of Bangladesh. UN Dev. Prog. Food and Agric. Org.:212-22

Walter I, Cuevas G, Garcia S, Martinez F (2000).Biosolid effects on soil and native plant production in a degraded semiarid ecosystem in central Spain.Waste Management Research.18: 259.

WHO (World Health Organization) (1996). Permissible limits of heavy metals in soil and plants Geneva: World Health Organization, Switzerland). 